\title{
Whistling invaders: Status and distribution of Johnstone's Whistling frog (Eleutherodactylus johnstonei Barbour, 1914), 25 years after its introduction to Colombia
}

\author{
Franziska Leonhardt ${ }^{1,2}$, Juan David Jimenez-Bolaño ${ }^{3}$, Raffael Ernst ${ }^{1}$
}

I Museum of Zoology, Senckenberg Natural History Collections Dresden, A. B. Meyer Building, Königsbrücker Landstraße 159, 01109 Dresden, Germany 2 Technical University of Dresden, Faculty of Biology, 01062 Dresden, Germany 3 Grupo de Investigación en Manejo y Conservación de Fauna, Flora y Ecosistemas Estratégicos Neotropicales (MIKU), University of Magdalena, Santa Marta, Colombia

Corresponding author: Raffael Ernst (raffael.ernst@senckenberg.de)

Academic editor: R. Colautti | Received 30 January 2019 | Accepted 1 April 2019 | Published 18 April 2019

Citation: Leonhardt F, Jimenez-Bolaño JD, Ernst R (2019) Whistling invaders: Status and distribution of Johnstone's Whistling frog (Eleutherodactylus johnstonei Barbour, 1914), 25 years after its introduction to Colombia. NeoBiota 45: 39-54. https://doi.org/10.3897/neobiota.45.33515

\begin{abstract}
Despite increased attention to the problem of alien amphibian invasions, systematic assessments of the actual invasion status and potential, required to estimate possible environmental and economic impacts of introduced species, are often missing. A prime example is Johnstone's Whistling Frog (Eleutherodactylus johnstonei), a Caribbean native that now occurs widely throughout the South American mainland, including Colombia. We conducted the first systematic and comprehensive countrywide assessment of the introduction status of the species in Colombia, combining both intensive field surveys, as well as a first population genetic analysis. The species was strictly confined to urban habitats with specific environmental conditions (plant nurseries and private gardens) and did not show any signs of dispersal into the extra-urban matrix. Genetic data support previously hypothesised independent introduction events in the Andes and along the Caribbean Coast and shed light on potential dispersal pathways. The results of this study challenge both the active spread, as well as the broad environmental tolerance hypothesis previously suggested, to explain the observed range extension. A critical reassessment of the categorisation of the species as highly invasive under IUCN-ISSG standards is required.
\end{abstract}

\section{Keywords}

Anura, alien amphibians; Colombia; distribution; disturbed areas; invasion status; new records; population genetics

Copyright Franziska Leonhardt et al. This is an open access article distributed under the terms of the Creative Commons Attribution License (CC BY 4.0), which permits unrestricted use, distribution, and reproduction in any medium, provided the original author and source are credited. 


\section{Introduction}

Johnstone's Whistling Frog, Eleutherodactylus johnstonei Barbour, 1914, a native of the Lesser Antilles, presumably St. Lucia or the northern Lesser Antilles (Kaiser 1997), has a long history of human mediated range expansion, dating back to at least 1880 when it was first discovered on Bermuda (reviewed in Kaiser 1997; Kraus 2008). Subsequently the species became established on other Caribbean Islands and on the Middle and South American mainland, with Sao Paolo, Brazil being the southernmost confirmed record to date (Melo et al. 2014). It is one of the few tropical species that even managed to establish populations in the temperate zones of the palearctic of Europe. However, this introduction occurred under very peculiar circumstances and here, the species is restricted to non-natural environments, namely botanical gardens and greenhouses. In Europe, the species was first recorded in the botanical garden of the University of Basel and its introduction was traced back to a plant shipment from Guadeloupe received in 1993 (H. Schneider pers. comm.). Today, at least 10 different greenhouse populations are known from zoological and botanical institutions in Germany and the Netherlands (this study).

Given this broad distribution (Fig.1), E. johnstonei can be considered one of the most widely and successfully expanding invasive amphibian species, outperformed probably only by the cane toad Rhinella marina (Kaiser 2002, IUCN-GISD 2018) and the American bullfrog Lithobates catesbeianus (Escoriza and Ruhí 2016). Earlier studies suggested that E. johnstonei actively disperses in a process of slow and steady migration events (e.g. Schwartz and Fowler 1973; for introduced populations on Jamaica). It was therefore expected to spread into natural habitats on several Lesser Antillean islands, where it was assumed to compete with endemic species (Hedges et al. 2010). Macroecological models, mainly based on coarse-grained climate data, even predict a very high invasion potential far beyond its natural Caribbean range (Rödder 2010) and the current distribution on the South American mainland seems to corroborate this notion. Despite this wide distribution, active dispersal beyond non-natural, human modified habitats could not convincingly be shown to be a realistic scenario (Kaiser 1997, 2002; Ernst et al. 2011). Yet, the majority of studies consider the invasion potential to be high and thus propose proactive eradication measures (Melo et al. 2014)

Amongst all countries, to which $E$. johnstonei has been introduced successfully, Colombia deserves special attention because of the comparatively long introduction history and the large number of populations reported to have established in different parts of the country. In the present study, we provide the first systematic and comprehensive countrywide assessment of the introduction status of E. johnstonei in Colombia. Known populations are reassessed and additional localities are investigated for the occurrence of the target species. For the first time, we assessed the species' population genetic structure in Colombia. We subsequently discuss the geographic distribution pattern in the light of the controversy surrounding the actual invasion potential of the species in Colombia and finally provide an outlook for future research directions. 


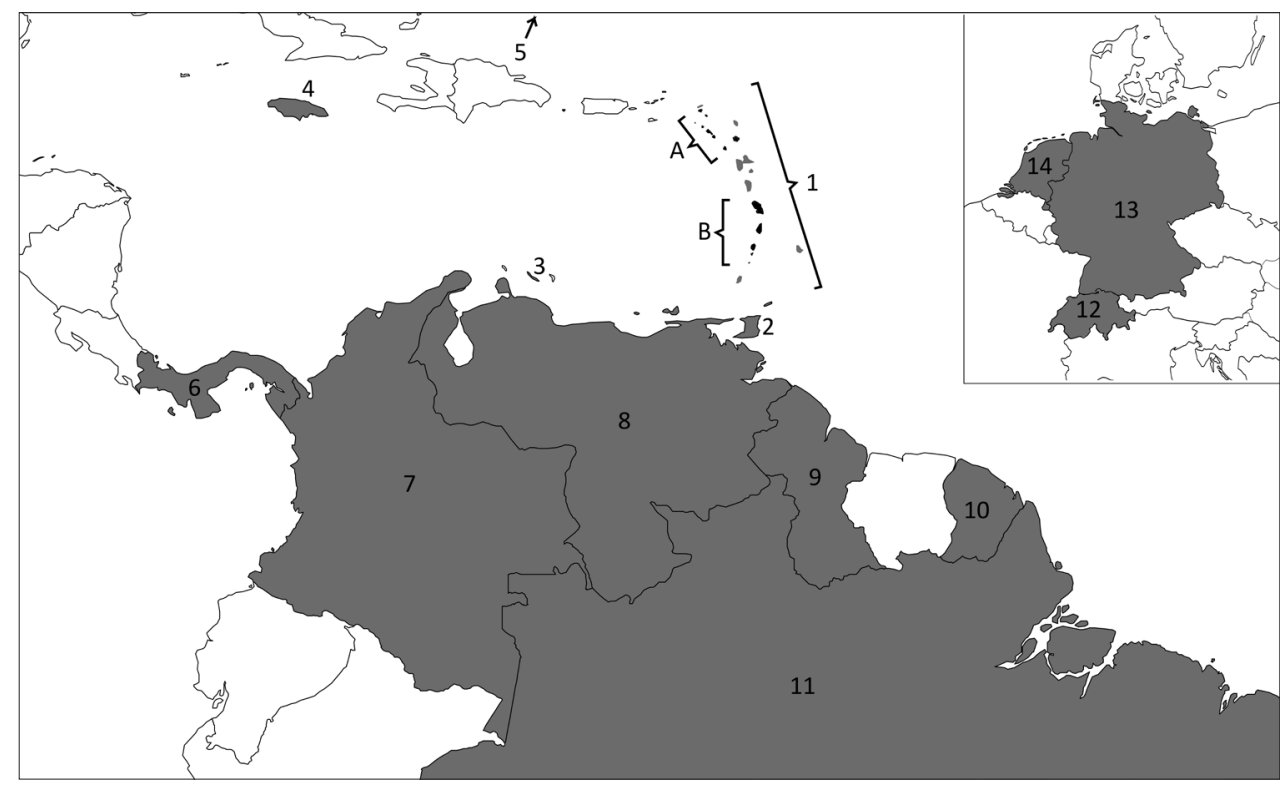

Figure I. Global (country-level) distribution of Eleutherodactylus johnstonei. Black, Presumed native range (A or B); grey, introduced range (1-13). A St Maarten/St Martin, Saba, St Eustatius, St Kitts and Nevis, Antigua (Kaiser 1997) B Montserrat, Martinique, St Lucia, St Vincent (Kaiser 1997); 1: Anguilla, Barbuda, Guadeloupe, Dominica, Barbados, Grenadines, Grenada (Kaiser 1997); 2: Trinidad (Hardy and Harris 1979); 3: Curaçao (Hardy and Harris 1979); 4: Jamaica (Barbour 1910); 5: Bermuda (Pope 1917); 6: Panama (Ibáñez and Rand 1990); 7: Colombia (Ruiz-Carranza et al. 1996); 8: Venezuela (Hardy and Harris 1979); 9: Guyana (Hardy and Harris 1979); 10: French-Guiana (Lescure and Marty 1996); 11: Brazil (Melo et al. 2014); Inset top right: Greenhouse populations in Europe: 12: Switzerland (this study); 13: Germany (this study); 14: Netherlands (this study).

\section{Methods}

\section{Study area}

To assess the countrywide distribution of E. johnstonei, we conducted opportunistic surveys, covering natural urban peripheral and urban areas, in all major biogeographic regions (Caribbean, Andean, Pacific, Orinoco and Amazonas region; Fig 2, Suppl. material 1: Table S1) of Colombia. In addition, we selected nine focus areas for systematic surveys (see below and Fig 2). These were located in the following regions: 1 . Santa Marta (12 $\mathrm{m}$ a.s.l.), 2. Barranquilla (24 $\mathrm{m}$ a.s.l.) and 3. Cartagena (34 $\mathrm{m}$ a.s.l.) in the Caribbean coastal lowlands; 4. Bucaramanga (993 m a.s.l.) and 5. Fusagasugá $(1,717 \mathrm{~m}$ a.s.l.) in the Eastern Andean Cordillera; 6. Ibagué (1,229 m a.s.l.) and 7. Mariquita ( $485 \mathrm{~m}$ a.s.l.) in the Central Andean Cordillera; 8. Medellín (1,500 m a.s.l.) and 9. Cali (967 $\mathrm{m}$ a.s.l.) in the western Andean Cordillera. The population size varies between localities, ranging from 500,000 inhabitants (Santa Marta, Bucara- 
manga and Ibagué) to 1 Mio (Cartagena, Barranquilla, Cali), and even up to 2.5 Mio (Medellin) in major urban centres to only approximately100,000 (Fusagasugá) and 33,000 (Mariquita), respectively. Given the broad altitudinal and geographic range covered, climate conditions vary significantly amongst the nine locations: Hot semiarid climate (Bsh) in Santa Marta $\left(>27^{\circ} \mathrm{C}\right.$, dry season [arid] Dec.-April); Tropical wet and dry climate (Aw) in Cartagena and Barranquilla $\left(>27^{\circ} \mathrm{C}\right.$, dry season [arid] Dec.-April), Fusagasugá and Cali $\left(>19^{\circ} \mathrm{C}\right.$, two dry and wet seasons [no arid month]) ; Tropical monsoon climate $(\mathrm{Am})$ in Medellín (average $21.6{ }^{\circ} \mathrm{C}$, less pronounced dry season); Tropical rainforest climate (Af) in Bucaramanga, Ibagué, Mariquita $\left(>21{ }^{\circ} \mathrm{C}\right.$, no dry season) (climate-data.org, categories according to Köppen 1936; Geiger 1961).

\section{Sampling strategy and data acquisition}

Occurrence data (presence-absence) in both urban and pristine areas were acquired through opportunistic visual and acoustic encounter surveys (VES and AES, following Rödel and Ernst 2004) conducted between 2016 and 2018, covering both rainy and dry season. Localities for systematic surveys in focus areas were chosen based on occurrence evidence derived from (1) literature, (2) museum vouchers listed in the online databases www.gbif.org and www.vertnet.org, (3) unpublished museum vouchers deposited in visited collections, (4) expert knowledge (personal communication) and (5) interviews with local stakeholders (For a full list of sample areas, including focus areas and sampled localities therein, consult the gazetteer in Suppl. material 1: Table S1). Institutional abbreviations used throughout the text are as follows: ICN, Museo de Historia Natural, Instituto de Ciencias Naturales, Universidad Nacional de Colombia, Bogotá; MTD, Museum für Tierkunde, Senckenberg Naturhistorische Sammlungen Dresden; UIS, Colección Herpetologia, Museo de Historia Natural, Universidad Industrial de Santander, Bucaramanga, Colombia; UVC, Museo de Vertebrados, Universidad del Valle, Cali, Colombia; CZA-UT, Colección Zoológica (Anfibios), Facultad de Ciencias, Universidad del Tolima, Ibagué, Tolima; MHUA-A, Museo de Herpetología (Anfibios), Universidad de Antioquia, Medellín, Colombia.

Systematic surveys in the nine urban focus areas were undertaken between June and August 2017 and in March 2018, thus covering both wet and dry season periods. We pre-selected at least two urban districts per focus area, in which two of us (FL and JDJB) conducted standardised VES and AES (following Rödel and Ernst 2004). The number of sampled localities varied for respective districts, due to differences in geographic extent and logistic restrictions (Suppl. material 1: Table S1). Each survey lasted from 6:00 $\mathrm{pm}-10: 00 \mathrm{pm}$ in respective localities. Presence-absence data include audiovisual records and collected vouchers. Specimens designated as collection vouchers were euthanised using commercially available toothache pain relief gel containing 20\% Benzocaine and subsequently preserved in $70 \%$ ethanol. Specimens are deposited in the collection of the ICN under collection numbers ICN 57694-57763 and ICN 57960-57962. Additional genetic samples were obtained by taking independent toe clips of uncollected 
individuals. We aimed at obtaining at least ten genetic samples per focus area for subsequent population genetic analysis (Suppl. material 1: Table S1). All genetic samples were stored in $95 \%$ ethanol. Clipped toes were subsequently disinfected using cotton pads soaked in $70 \%$ ethanol to prevent infections and individuals were immediately released on the spot. Genetic samples are deposited in the tissue collection at MTD.

\section{Population genetic analyses}

A total of 69 tissue samples from all sampled localities were used to generate mitochondrial (mt) haplotypes from partial sequences of $12 \mathrm{~S}$ rRNA and D-loop regions, two established mt-markers previously used for population genetic and phylogeographic analyses in congeneric species (Barker and Rodríguez-Robles 2017; Rodríguez et al. 2010). DNA was isolated from tissue samples using the innuPREP DNA Mini Kit (Analytik Jena AG, Jena, Germany), protocol 1: DNA extraction from tissue samples. For PCR amplification of the 12S rRNA sequences primers L25195 (forward, 5'-AAA CTG GGA TTA GAT ACC CCA CTA T-3') and H2916 (reverse, 5'-GAG GGT GAC GGG CGG TGT GT-3') from Palumbi et al. (1991) following Vences et al. (2000) were used with the following conditions on an Eppendorf Mastercycler: initial denaturation at $94^{\circ} \mathrm{C}$ for $5 \mathrm{~min}, 35$ cycles with denaturation at $94^{\circ} \mathrm{C}$ for $45 \mathrm{~s}$, annealing at $55^{\circ} \mathrm{C}$ for $45 \mathrm{~s}$ and extension at $72{ }^{\circ} \mathrm{C}$ for $1 \mathrm{~min}$, with a final extension at $72{ }^{\circ} \mathrm{C}$ for $10 \mathrm{~min}$. For amplification of a D-loop fragment, primers Eleu-CR-1-For (5'-TCCWGTTGWCWRGGATAGAGAAGG-3') and Eleu-CR-2-Rev (5'-GAAYATATRTTCTCCTATGATGG-3') were designed, based on an alignment of existing D-loop sequences for the genus Eleutherodactylus available on NCBI GenBank. The following PCR conditions were used: initial denaturation at $94^{\circ} \mathrm{C}$ for $5 \mathrm{~min}, 40$ cycles with denaturation at $94^{\circ} \mathrm{C}$ for $20 \mathrm{~s}$, annealing at $45^{\circ} \mathrm{C}$ for $30 \mathrm{~s}$ and extension at $72{ }^{\circ} \mathrm{C}$ for $2 \mathrm{~min} 30 \mathrm{~s}$, with a final extension at $72{ }^{\circ} \mathrm{C}$ for $10 \mathrm{~min}$. The total reaction volume of $20 \mu \mathrm{l}$ contained $1 \mu \mathrm{l}$ template DNA, $0.2 \mu \mathrm{l}$ Taq Polymerase (Roth), $2 \mu \mathrm{l}$ reaction

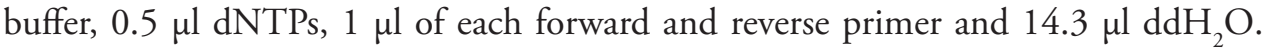
PCR products were purified using the ExoSAP-IT PCR Product Cleanup Reagent (Applied Biosystems; 1:20 dilution; modified protocol: $30 \mathrm{~min}$ at $37{ }^{\circ} \mathrm{C}, 15 \mathrm{~min}$ at $80^{\circ} \mathrm{C}$ ). For sequencing, BigDye Terminator v3.1 Cycle Sequencing Kit (Applied Biosystems) with the respective forward primers (as used for PCR amplification) was used with the following conditions: initial denaturation at $96^{\circ} \mathrm{C}$ for $1 \mathrm{~min}, 25$ cycles with denaturation at $96^{\circ} \mathrm{C}$ for $10 \mathrm{~s}$, annealing at $50^{\circ} \mathrm{C}$ for $5 \mathrm{~s}$, elongation at $60^{\circ} \mathrm{C}$ for 1 min 15 s. Cycle sequencing reaction products were purified using the Performa DTR V3 96-Well Short Plate (Edge Biosystems, Gaithersburg, MD, USA), with each well filled with $400 \mu$ l Sephadex ${ }^{\text {TM }}$ (GE Healthcare, 1:20 solution). In total, we successfully generated 69 partial $12 S$ rRNA sequences (360 bp) and 48 partial sequences of the Dloop region $(249 \mathrm{bp})$. All D-loop sequences and a single $12 \mathrm{~S}$ rRNA sequence (identical for all analysed samples) are deposited in NCBI GenBank under accession numbers LR215271-LR215318 (D-Loop) and LR215270 (12S rRNA). After manually align- 
ing sequences using BIOEDIT Sequence Alignment Editor 7.2.5 (Hall 1999), a haplotype network was generated with POPART (Leigh and Bryant 2015). All available network inference methods (Minimum Spanning Network, Median Joining Network, Integer Neighbour-Joining, Tight Span Walker, TCS network) yielded identical results; the Integer Neighbour-Joining Network was used to represent the haplotype network.

\section{History of introduction to Colombia}

The first published record of E. johnstonei for Colombia dates back to 1992. The species was reported for Barranquilla (Ruiz-Carranza et al. 1996) and the record is likely based on the first collected specimen (ICN 40380, collected 1992 by J.V. Rueda A.). Ruiz-Carranza et al. (1996) do not provide any information on potential introduction pathways, but it is likely that the species was unintentionally introduced via the ornamental plant trade (Kaiser 1997). A possible second, independent introduction was reported for Bucaramanga, where the species was sold and intentionally released to enrich gardens and yards of private properties (Ortega et al. 2001; UIS A346-350 collected 1996). In both cases, neither the origin of the frogs is clear, nor whether these introductions can actually be considered to represent two independent events, as individuals sold in Bucaramanga may have been transferred from Barranquilla. Although several single locality records have previously been published, no comprehensive assessment of the distribution and potential dispersal pathways of E. johnstonei throughout Colombia is available to date. The most recent status report for the country is included in a broader continental assessment compiled by Kaiser (2002). At the time of publication, only three confirmed locality records were available. These include the above-mentioned records for Barranquilla and Bucaramanga, as well as specimens collected in Cali (UVC 13885-13904, collected by W. Bolívar in 1998). In addition, an unconfirmed record based on a personal communication by J.D. Lynch was given for Cartagena. More recently, the species has been reported for Mariquita (Montes and Bernal 2012; confirmed by vouchers CZA-UT 1259, 1260), Ibagué (Llano-Mejía et al. 2014; Gómez-Martínez et al. 2016; not confirmed by vouchers) and Fusgasugá (Gómez-Martínez et al. 2016, not confirmed by vouchers). Without exception, all previous records of E. johnstonei in Colombia came from urban areas where individuals mostly occupy private gardens or nurseries. However, Córdoba Hernández (2014) reports E. johnstonei from an urban riverside, namely the Meléndez river in Cali, which is dominated by pasture and shrubs.

\section{Results}

\section{Distribution and status of introduction in Colombia}

The presence of E. johnstonei was confirmed for three out of the five major geographic areas in Columbia. These include the costal lowlands of the Caribbean region and the 


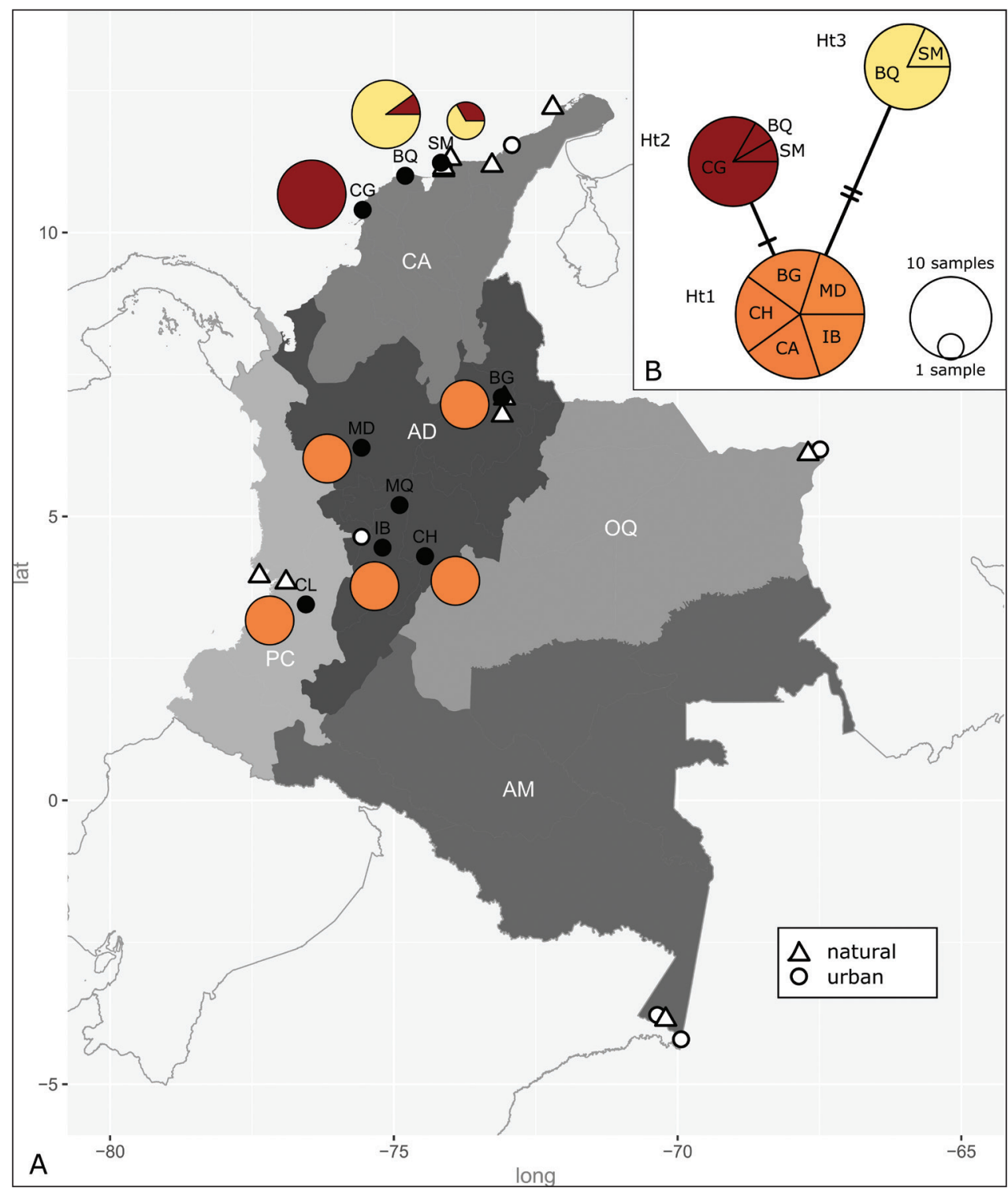

Figure 2. Presence-absence and haplotype distribution (A) and network (B) for Eleutherodactylus johnstonei in Colombia. A Small symbols: circles = urban areas; triangles = natural areas; filled symbols = presence, blank symbols = absence. White labels encode major geographic regions based on affiliation of administrative regions (www.colombia.com/colombia-info/informacion-general/geografia/regiones/): CA, Caribbean region; AD, Andean region; PC, Pacific region; OQ, Orinoco region; AM, Amazonas region. Black labels encode cities with presence of E. johnstonei: SM, Santa Marta; BQ, Barranquilla; CG, Cartagena; BG, Bucaramanga; MD, Medellín; MQ, Mariquita; IB, Ibague; $\mathrm{CH}$, Fusagasuga-Chinauta; $\mathrm{CL}$, Cali. Large coloured circles present haplotype frequencies at sampled localities. Orange: $\mathrm{Ht} 1$, red: $\mathrm{Ht} 2$, yellow: Ht3; circle sizes refer to numbers of samples at each locality as illustrated in inlet B Haplotype network based on the Integer-Neighbour-Joining Network implemented in POPART (Leigh and Bryant 2015). Mutations segregating haplotypes are depicted as hatch marks; partitions illustrate localities (abbreviations as in $\mathbf{A}$ ) featuring the respective haplotype; circle and partition sizes represent numbers of samples. 
Eastern, Central and Western Andes within the Andean and the Pacific Region. Unlike previous reports, these records are based on multiple evidence (visual, acoustic and voucher records). We could not find any evidence for the presence of the target species along the Pacific coast and in the Amazon and Orinoco region. Moreover, opportunistic VES and AES did not yield records outside of urban areas in any of the investigated regions throughout Colombia (see Fig. 2). Voucher specimens and audio-visual evidence confirm previously published records for Barranquilla (ICN 57694-57710), Bucaramanga (ICN 57732-57736), Cali (ICN 57756, 57757) and Mariquita (audiovisual evidence). For the first time, voucher specimens and tissue samples were collected for previously reported localities at Fusagasugá (ICN 57758-57763), Cartagena (ICN 57711-57731) and Ibagué (ICN 57744-57755), thus confirming previous reports based on visual and acoustic evidence (Gómez-Martínez et al. 2016; Kaiser 2002). The proposed occurrence at Medellin, based on unpublished museum vouchers (J.M. Daza pers. comm.; MHUA-A 10333, 10334), was confirmed and additional vouchers were added to these records (ICN 57737-57743). Finally, our surveys resulted in the discovery of a previously unreported population at the Caribbean coast of Santa Marta (ICN 57960-57962). In total, we were able to confirm and/or establish the occurrence of E. johnstonei for nine localities. Three are located in the Caribbean and two each in the Eastern, Western and Central Andean Cordillera, respectively (see Fig. 2). At all sampled localities, E. johnstonei exclusively occupied nurseries and urban private gardens in front of private houses, apartment complexes or hotels, while we never found populations in other urban areas such as public parks or gardens, even if these were located in the immediate vicinity of occupied sites. The observed general occurrence pattern was thus scattered within particular city districts, rather than continuous across the entire urban matrix. In total, we intensively surveyed 52 independent sites within and across our nine urban focus areas (see Suppl. material 1: Table S1). The majority of surveyed sites (67\%) exhibited low abundances ( $\leq 5$ calling males per site/survey), while we recorded intermediate abundances (6-15 calling males) for $21 \%$ and high abundances (> 15 calling males) for only $14 \%$ of all surveyed sites. All sites (9 total), located in the cities of Fusagasugá, Mariquita, Medellín and Santa Marta, exhibited lowest abundances, whereas sites with highest abundance levels were exclusively found in Barranquilla, Bucaramanga and Cartagena.

\section{Population genetic patterns}

$12 \mathrm{~S}$ rRNA mitochondrial marker sequences (360 bp, partial sequence) did not show any variation amongst the 69 samples collected across the entire Colombian distributional range. However, a clear differentiation existed in respective D-loop sequences (249 bp, partial sequence). Nucleotide diversity amongst the 48 individuals, for which sequences could be generated, amounted to $0.46 \%$ with a maximum of three variable sites, revealing three distinct haplotypes (Ht, see Table 1$)$. Ht 1 , the most common haplotype (52\% of all samples) was detected in all populations except those from the Caribbean coast. 
Table I. Haplotype distribution at sampled localities. N, number of individuals sampled per locality, haplotype $(\mathrm{Ht})$ diversity and haplotype frequencies at each locality.

\begin{tabular}{|c|c|c|c|c|c|}
\hline \multirow{2}{*}{ Locality } & \multirow{2}{*}{$\mathbf{N}$} & \multirow{2}{*}{ Haplotype diversity } & \multicolumn{3}{|c|}{ Haplotype frequency } \\
\hline & & & GGT (Ht1) & GGC (Ht2) & AAT (Ht3) \\
\hline Barranquilla & 10 & 0.18 & & 0.1 & 0.9 \\
\hline Cartagena & 10 & 0 & & 1.0 & \\
\hline Santa Marta & 3 & 0.67 & & 0.33 & 0.67 \\
\hline Bucaramanga & 5 & 0 & 1.0 & & \\
\hline Medellin & 5 & 0 & 1.0 & & \\
\hline Ibagué & 5 & 0 & 1.0 & & \\
\hline Cali & 5 & 0 & 1.0 & & \\
\hline Fusgasugá & 5 & 0 & 1.0 & & \\
\hline Total & 48 & 0.61 & 0.52 & 0.25 & 0.23 \\
\hline
\end{tabular}

On the other hand, $\mathrm{Ht} 2$ and $\mathrm{Ht} 3$, both diverging from $\mathrm{Ht} 1$ by one and two mutations, respectively, were exclusively present in populations of the Caribbean coast. Here, tested individuals from populations in Cartagena exclusively belong to $\mathrm{Ht} 2$, while populations from Barranquilla and Santa Marta both share Ht2 as well as Ht3 (see Fig. 2).

\section{Discussion}

\section{Status of introduction and invasion potential}

Roughly 25 years after its introduction to Colombia, E. johnstonei has managed to establish populations in nine different urban areas, ranging from the Caribbean Coast at almost sea level to the Andes at altitudes of more than 1,700 m a.s.l. Climatic conditions in these newly colonised localities vary significantly and comprise arid to semiarid as well as tropical wet environments. Mean annual temperatures range from as low as $19.4^{\circ} \mathrm{C}$ (Fusagasugá, $1,717 \mathrm{~m}$ a.s.l.) to as high as $28.3^{\circ} \mathrm{C}$ (Santa Marta, $12 \mathrm{~m}$ a.s.l.).

This broad environmental gradient implies a significant environmental tolerance and, in combination with the comparatively wide geographic distribution across the country, it appears to corroborate results from macroecological models predicting significant future range extensions (Rödder 2010). This notion receives further support when considering the apparent speed of the range expansions from a single known introduction locality in 1992 (Ruiz-Carranza et al. 1996) to four known localities in 2002 (Kaiser 2002) and already nine confirmed localities to date (this study), reflecting the overall global expansion trend of the species within the last two decades.

However, this macro-perspective is misleading. A rather different interpretation suggests itself, when considering small-scale spatial patterns and local environmental features obtained from field surveys. A look at the spatial pattern of distribution reveals markedly disjunct distributions at larger geographic scales (countrywide distribution) that are recursively replicated at smaller geographic scales (within cities). This pattern confirms earlier findings suggesting human facilitated jump dispersal (Ernst et 
al. 2011; Kaiser 2002), rather than active spread leading to continuous distributions along an "invasion front" (e.g. Phillips et al. 2007).

A prevalence for site tenacity and very small home ranges $\mathrm{d}(\leq 2 \mathrm{~m}$ in diameter) has previously been shown in a study on long-term and nightly movement patterns in E. johnstonei in Barbados (Ovaska 1992). This is reflected in our observations from urban populations in Colombia. Here, we found the species in small private front yards in direct vicinity to public recreational parks, without ever recording individuals from within the parks' boundaries, even when these contained large numbers of ornamental plants that otherwise represent favourable reproductive habitats and provide male calling perches. A consistent absence of $E$. johnstonei in vegetation patches, neighbouring ornamental plants in Bucaramanga, was previously reported by Ortega et al. (2001). This pattern was confirmed in the present study, indicating that no significant migration into the surrounding matrix took place within the past 16 years. A low capacity for active dispersal was previously also reported for non-native populations in French Guiana (Ernst et al. 2011). It is well known that significant lag phases can exist between particular invasion phases (Kowarik 1995) and land use changes, including growth and expansion of urban centres may enhance further spread of the species by counteracting present day dispersal limitations. However, there is no evidence that this will alter the species' ecological response capacity in the short term, thus allowing for active dispersal into pristine habitats.

We therefore conclude that the active invasion potential seems to be very limited and distributional extensions are rather determined by the availability and frequency of passive transportation mediated by human transport.

When considering site-specific attributes, a second non-random pattern emerges that challenges both the active spread as well as the broad environmental tolerance hypothesis. Again this pattern is somewhat recursive as it can be observed at two spatial scales. At the country level, E. johnstonei is restricted to urban or disturbed urban peripheral areas as previously reported from countries outside the native range (e.g. Ernst et al. 2011; Kaiser 2002; Montes and Bernal 2012). Moreover, the distribution within the respective urban matrix is not random but habitat specific. In Colombia, the species was exclusively found in plant nurseries and private gardens that provide very specific microclimatic conditions, somewhat independent from overall climatic conditions in the surrounding landscape matrix. Regular watering and artificial provisioning of structural habitat elements that are exploited for reproduction (plants and moist substrate) may create more favourable and stable conditions than in comparative unattended, (semi-) natural habitats and thus allow for continuous rather than seasonally limited reproduction (Bourne 1998; Ortega et al. 2005). This, in turn, facilitates the establishment of stable populations by increasing propagule pressure (sensu Lockwood et al. 2005). The above-described localities can therefore be considered as artificial, semi-natural outdoor enclosures, rather comparable to greenhouse environments, from which the species is reported in Europe. This casts serious doubt on the definition of "invasive" itself, as the establishment criterion sensu Blackburn et al. (2011), which requires self-sustaining populations in the wild, may not be fulfilled. If habitat suit- 
ability models, designed to predict future range expansions, are exclusively based on coarse-grained occurrence data in combination with macroecological predictors and include occurrences from within the exotic range of the species, this would have severe consequences for the model outcome. Under the described scenario, standard modelling schemes would be similar to using occurrence data from zoological and botanical gardens in Europe to predict potential range extensions in continental South America and beyond. The distinction between using exotic range data from continental South America and greenhouse data from European distributions may thus simply be a matter of degree of difference. However, it is far from being merely a semantic question, as ignoring the above-mentioned small-scale factors will certainly lead to flawed and imprecise (most likely exaggerated) model predictions.

Overall, our results are in line with studies that report $E$. johnstonei exclusively from non-natural, urban areas in Colombia (e.g. Córdoba Hernández 2014; Gómez-Martínez et al. 2016; Montes and Bernal 2012). However, in contrast to these, we consider the potential to actively spread and become established in natural areas, thereby negatively impacting native species, as comparatively low. Despite reported negative economic impacts imposed by $E$. johnstonei, there are currently no studies that convincingly show negative environmental impacts (Measey et al. 2016), probably also because interactions with native fauna are limited due to the strict confinement of the species to urban areas. A critical reassessment of the categorisation of the species under IUCN-ISSG standards (compare Global Invasive Species Database www.issg.org) is thus required.

\section{Origins and history of introduction}

Despite obvious limitations with respect to genetic sample sizes $(N=69 / 48)$, as well as limited choice of molecular markers (two different markers covering a total of $609 \mathrm{bp}$ ) that prove to be applicable in the current analytical framework, we were able to retrieve first informative patterns describing the population genetic setup of the Colombian populations under investigation. The macro-scale pattern (coastal vs. hinterland populations) is likely to prove robust and should be confirmed in future studies. With only $0.46 \%$ nucleotide divergence and only three variable sites recovered, the overall genetic diversity amongst the Colombian populations is much lower than expected, based on the limited data available from studies on congeneric frog species from the Caribbean that used similar markers (Barker et al. 2012; Barker and Rodríguez-Robles 2017). However, since we were not able to include samples from native range populations in our analyses, the crucial question of how genetically diverse these island populations are to begin with, remains to be answered in a more comprehensive future study. Studies on genetic diversity within and amongst introduced and native E. johnstonei populations are so far completely lacking. Our study thus provides first data on any of the known populations. It thus represents a necessary first step in addressing these questions.

The observed geographic distribution of D-loop haplotypes (see Figure 2) supports the assumption of at least two independent introductions. Haplotype $\mathrm{Ht} 1$ is not 
present along the Caribbean coast. Instead it is the single haplotype observed in all Colombian hinterland populations. A second independent introduction to Bucaramanga and subsequent translocations to other interior localities, previously hypothesised by Ortega et al. (2001), thus becomes likely. The distribution of the haplotypes Ht2 and $\mathrm{Ht} 3$ along the Caribbean Coast is consistent with an introduction scenario, previously outlined by Ruiz-Carranza et al. (1996) and receives additional support from plant trade information provided by local nursery owners. In this scenario, individuals carrying Ht3 were originally introduced to Barranquilla, from where they were transferred to Santa Marta. However, this haplotype is missing from Cartagena. The distribution of the second haplotype, Ht2, which is found in all three Caribbean localities, including Cartagena, where it represents the only haplotype detected, hints at a possible third independent introduction. Evidence for this scenario comes from anecdotal reports of a deliberate introduction of frogs of unknown origin in private gardens in Cartagena. Local nursery owners report frequent transports of plant material to Barranquilla and Santa Marta, opening possible pathways for the introduction of Ht2 to these cities. Since genetic differentiation between $\mathrm{Ht} 1, \mathrm{Ht} 2$ and $\mathrm{Ht} 3$ is relatively weak, with only one mutation between $\mathrm{Ht} 1$ and $\mathrm{Ht} 2$ and two mutations, between $\mathrm{Ht} 1$ and $\mathrm{Ht} 3$, respectively, we cannot completely rule out the possibility that both Ht2 and $\mathrm{Ht} 3$ derived from $\mathrm{Ht} 1$ by mutational steps. However, this seems very unlikely, as these haplotypes are geographically strictly separated by large distances and have not been found to co-occur in any of the investigated sites. A robust test of the outlined scenarios certainly requires additional genetic sampling and, ideally, the application of higher resolution markers.

\section{Conclusion}

The results of our study underscore the need to critically reassess the actual distribution status and dispersal potential of Johnstone's Whistling Frog in its non-native range and re-evaluate the current classification as an extensively spreading invasive amphibian species. Both the observed historic dispersal patterns revealed through a first population genetic assessment of the Colombian populations, as well as the actual present distributional patterns retrieved through intense field surveys, challenge available model predictions that are based on macro-ecological descriptors and coarse-scale climatic variables. Based on the two lines of evidence (molecular and field-data) provided in this study, we consider the current risk of further range extensions into natural or even ex-urban areas as very low but recommend intensified surveys in non-urban areas. In keeping with Mecke (2014), we caution against disproportionate and premature countermeasures including eradication programmes (compare Melo et al. 2014). We rather advocate intensified systematic monitoring of the species. Moreover, increased genetic sampling is required to verify or revise the uncovered population genetic pattern and shed light on potential dispersal pathways that may have remained undetected. Despite the fact that threats to native biota imposed by direct interactions with $E$.johnstonei 
appear to be limited, we cannot rule out indirect negative effects mediated through the co-introduction of pathogenic microbiota associated with E. johnstonei (nested invasions, see current debate related to BSal, Martel et al. 2014). These factors should be addressed in an extended analytical framework and ideally applied to non-native populations in Colombia and across the entire native and introduced range of the species.

\section{Acknowledgements}

Permission for fieldwork was given by the government of Colombia, Ministry of Environment and Sustainable Development, through resolution no. 0255 (permiso marco otorgado a la UNC de recolección de especímenes de especies silvestres de la diversidad biológica con fines de investigación científica no comercial para la asignatura 'Conservación genética'). Export of genetic samples was authorised by the Colombian "Autoridad Nacional de Licancias Ambientales" under reference number 20180605782-000. We are particularly indebted to M. Vargas-Ramírez for his help in obtaining permission, as well as for providing logistic support during fieldwork. We especially like to thank all local partners who granted access to their private properties. Without this support, fieldwork would not have been possible. C. Kehlmaier, A. Müller and H. Stuckas significantly supported the lab work and helped with primer design. We thank D. Escoriza and W. Dawson for their valuable comments on our manuscript.

\section{References}

Barker BS, Rodríguez-Robles JA (2017) Origins and Genetic Diversity of Introduced Populations of the Puerto Rican Red-Eyed Coquí, Eleutherodactylus antillensis, in Saint Croix (U.S. Virgin Islands) and Panamá. Copeia 105: 220-228. https://doi.org/10.1643/CG16-501. https://doi.org/10.1643/CG-16-501

Barker BS, Rodríguez-Robles JA, Aran VS, Montoya A, Waide RB, Cook JA (2012) Sea level, topography and island diversity: phylogeography of the Puerto Rican Red-eyed Coquí, Eleutherodactylus antillensis. Molecular Ecology 21: 6033-6052. https://doi.org/10.1111/mec.12020

Blackburn TM, Pyšek P, Bacher S, Carlton JT, Duncan RP, Jarošík V, Wilson JRU, Richardson DM (2011) A proposed unified framework for biological invasions. Trends in Ecology and Evolution 26: 333-339. https://doi.org/10.1016/j.tree.2011.03.023

Bourne GR (1998) Amphisexual parental behavior of a terrestrial breeding frog Eleutherodactylus johnstonei in Guyana. Behavioral Ecology 9: 1-7. https://doi.org/10.1093/beheco/9.1.1

Córdoba Hernández OD (2014) Food Habits for a Population of Eleutherodactylus johnstonei in an Area on the Bank of River Melendez, South of Cali, Valle del Cauca. Revista de Ciencias 18: 153160. http://www.scielo.org.co/scielo.php?script=sci_arttext\&pid=S0121-19352014000200011 Crump ML, Scott Jr NJ (1994) Visual encounter surveys. In: Heyer WR, Donnelly MA, McDiarmid RW, Hayek LC, Foster MS (Eds) Measuring and Monitoring Biological Diversity: Standard Methods for Amphibians. Smithsonian Institution, Washington, DC, 84-92. 
Ernst R, Massemin D, Kowarik I (2011) Non-invasive invaders from the Caribbean: the status of Johnstone's Whistling frog (Eleutherodactylus johnstonei) ten years after its introduction to Western French Guiana. Biological Invasions 13: 1767-1777. https://doi.org/10.1007/ s10530-010-9930-5

Escoriza D, Ruhí, A (2016) Functional distance to recipient communities may favour invasiveness: insights from two invasive frogs. Diversity and Distributions 22: 519-533. https:// doi.org/10.1111/ddi.12421

Geiger R (1961) Überarbeitete Neuausgabe von Geiger, R.: Köppen-Geiger / Klima der Erde (Wandkarte, 1:16 Mill.).

Gómez-Martínez MJ, Llano-Mejía J, Cortés-Gómez ÁM (2016) Presencia de Eleutherodactylus johnstonei (Anura: Eleutherodactylidae) en Ibagué, Tolima, Colombia: El papel de los viveros comerciales. Boletín Científico. Centro de Museos. Museo de Historia Natural 20: 164-170. https://doi.org/10.17151/bccm.2016.20.2.12

Hall TA (1999) BioEdit: a user-friendly biological sequence alignment editor and analysis program for Windows 95/98/NT. Nucleic Acids Symposium Series 41: 95-98. http:// jwbrown.mbio.ncsu.edu/JWB/papers/1999Hall1.pdf

Hedges B, Ibéné B, Breuil M, Powell R (2010) Eleutherodactylus pinchoni. The IUCN Red List of Threatened Species 2010: e.T56860A11546413. https://doi.org/10.2305/IUCN. UK.2010-2.RLTS.T56860A11546413.en

Kaiser H (2002) Expansion of Eleutherodactylus johnstonei in Northern South America: Rapid Dispersal Through Human Interactions. South American Journal of Herpetology 3: 229238. https://doi.org/10.2994/1808-9798-3.3.229

Kaiser H (1997) Origins and introductions of the Caribbean frog, Eleutherodactylus johnstonei (Leptodactylidae): management and conservation concerns. Biodiversity and Conservation 6: 1391-1407. https://doi.org/10.1023/A:1018341814510

Köppen W (1936) Das geographische System der Klimate. Handbuch der Klimatologie Bd. 1, Teil C.

Kowarik I (1995) Time-lags in biological invasions. In: Pyŝek P, Prach K, Rejmánek M, Wade M (Eds) Plant invasions. General aspects and special problems. SPB Academic Publication, Amsterdam.

Kraus F (2008) Alien reptiles and amphibians: a scientific compendium and analysis. Springer Science \& Business Media.

Leigh JW, Bryant D (2015) popart: full-feature software for haplotype network construction. Methods in Ecology and Evolution 6: 1110-1116. https://doi.org/10.1111/2041210X.12410

Llano-Mejía J, Cortés-Gómez ÁM, Gómez-Martínez MJ, Certuche-Cubillos JK, Sánchez A, Cortés M, Garzón D, Quintero D, Osorio L, Tolosa Y, Guzmán L (2014) Eleutherodactylus johnstonei en la ciudad de Ibagué: algunas anotaciones sobre su proceso de invasión. Presented at the IV Congreso Colombiano de Zoología, X Congreso Latinoamericano de Herpetología, X Congreso de la Sociedad Latinoamericana de Especialistas en Mamíferos Acuáticos (SOLAMAC) y VII Encuentro Colombiano Sobre Abejas Silvestres., Cartagena de Indias, Colombia, December 2014. 
Lockwood JL, Cassey P, Blackburn T (2005) The role of propagule pressure in explaining species invasions. Trends in Ecology \& Evolution 20: 223-228. https://doi.org/10.1016/j. tree.2005.02.004

Martel A, Blooi M, Adriaensen C, Van Rooij P, Beukema W, Fisher MC, Farrer RA, Schmidt BR, Tobler U, Gok K, Lips KR, Muletz C, Zamudio KR, Bosch J, Lötters S, Wombwell E, Garner TWJ, Cunningham AA, Spitzen-van der Sluijs A, Salvidio S, Ducatelle R, Nishikawa K, Nguyen TT, Kolby JE, Van Bocxlaer I, Bossuyt F, Pasmans F (2014) Recent introduction of a chytrid fungus endangers Western Palearctic salamanders. Science 346: 630-631. https://doi.org/10.1126/science.1258268

Mecke S (2014) Invasive species: review risks before eradicating toads. Nature 511: 534. https:// doi.org/10.1038/511534c

Measey GJ, Vimercati G, Villiers FA de, Mokhatla M, Davies SJ, Thorp CJ, Rebelo AD, Kumschick S (2016) A global assessment of alien amphibian impacts in a formal framework. Diversity and Distributions 22: 970-981. https://doi.org/10.1111/ddi.12462

Melo MA, Lyra ML, Brischi AM, Geraldi VC, Haddad CF (2014) First record of the invasive frog Eleutherodactylus johnstonei (Anura: Eleutherodactylidae) in São Paulo, Brazil. Salamandra 50: 177-180. http://www.salamandra-journal.com/index.php?option=com_ docman\&task=doc_download\&gid=373\&Itemid=76

Montes CM, Bernal MH (2012) Geographic distribution: Eleutherodactylus johnstonei. Herpetological Review 43: 439. https://ssarherps.org/herpetological-review-pdfs/

Ortega JE, Jerez A, Ramírez-Pinilla MP (2001) Geographic distribution: Eleutherodactylus johnstonei. Herpetological Review 32: 269. https://ssarherps.org/herpetological-review-pdfs/

Ortega JE, Serrano VH, Ramírez-Pinilla MP (2005) Reproduction of an introduced population of Eleutherodactylus johnstonei at Bucaramanga, Colombia. Copeia 2005: 642-648. https://doi.org/10.1643/CH-04-223R1

Ovaska K (1992) Short-and long-term movements of the frog Eleutherodactylus johnstonei in Barbados, West Indies. Copeia 1992: 569-573. https://doi.org/10.2307/1446223

Palumbi S, Martin A, Romano S, Mc Millan WO, Stice L, Grabowski G (1991) The simple fool's guide to PCR. Honolulu: Department of Zoology and Kewalo Marine Laboratory, University of Hawaii.

Phillips BL, Brown GP, Greenlees M, Webb JK, Shine R (2007) Rapid expansion of the cane toad (Bufo marinus) invasion front in tropical Australia. Australian Ecology 32: 169-176. https://doi.org/10.1111/j.1442-9993.2007.01664.x

Rödder D (2010) Human Footprint, facilitated jump dispersal, and the potential distribution of the invasive Eleutherodactylus johnstonei Barbour 1914 (Anura Eleutherodactylidae). Tropical Zoology 22: 205-217. http://www.fupress.net/index.php/tropicalzoology/article/view/4915

Rödel M-O, Ernst R (2004) Measuring and monitoring amphibian diversity in tropical forests. I. An evaluation of methods with recommendations for standardization 10: 1-14.

Rodríguez A, Vences M, Nevado B, Machordom A, Verheyen E (2010) Biogeographic origin and radiation of Cuban Eleutherodactylus frogs of the auriculatus species group, inferred from mitochondrial and nuclear gene sequences. Molecular Phylogenetics and Evolution 54: 179-186. https://doi.org/10.1016/j.ympev.2009.08.023 
Ruiz-Carranza PM, Ardila-Robayo MC, Lynch JD (1996) Lista actualizada de la fauna de Amphibia de Colombia. Revista de la Academia Colombiana de Ciencias Exactas, Físicas y Naturales 20: 365-415.

Schwartz, Albert, Fowler, Danny C (1973) The Anura of Jamaica: a progress report. Studies on the Fauna of Curaçao and other Caribbean Islands 43: 50-142. http://www.repository. naturalis.nl/record/506136

Vences M, Kosuch J, Lötters S, Widmer A, Jungfer K-H, Köhler J, Veith M (2000) Phylogeny and Classification of Poison Frogs (Amphibia: Dendrobatidae), Based on Mitochondrial $16 S$ and 12S Ribosomal RNA Gene Sequences. Molecular Phylogenetics and Evolution 15: 34-40. https://doi.org/10.1006/mpev.1999.0738

\section{Supplementary material I}

\section{Table S1}

Authors: Franziska Leonhardt, Juan David Jimenez-Bolaño, Raffael Ernst

Data type: occurence

Explanation note: Presence-absence data for Eleutherodactylus johnstonei in Colombia. Copyright notice: This dataset is made available under the Open Database License (http://opendatacommons.org/licenses/odbl/1.0/). The Open Database License $(\mathrm{ODbL})$ is a license agreement intended to allow users to freely share, modify, and use this Dataset while maintaining this same freedom for others, provided that the original source and author(s) are credited.

Link: https://doi.org/10.3897/neobiota.45.33515.suppl1 